\title{
THE ELABORATION OF CHEESE MASSES OF THERAPEUTIC AND PROPHYLACTIC DIRECTION WITH CRYOADDITIVE "PUMPKIN"
}

\author{
Bogdan Gutyj \\ Department of Pharmacology and Toxicology \\ Lviv National University of Veterinary Medicine and Biotechnologies named after S. Z. Gzhytskyi \\ 50 Pekarska str., Lviv, Ukraine, 79010 \\ bvh@ukr.net \\ Yuriy Hachak \\ Department of Technology of milk and milk products \\ Lviv National University of Veterinary Medicine and Biotechnologies named after S. Z. Gzhytskyi \\ 50 Pekarska str., Lviv, Ukraine, 79010 \\ gachak61@mail.ru \\ Jaroslava Vavrysevych \\ Department of Biological and General Chemistry \\ Lviv National University of Veterinary Medicine and Biotechnologies named after S. Z. Gzhytskyi \\ 50 Pekarska str., Lviv, Ukraine, 79010 \\ GutaZor@gmail.com \\ Volodimyra Nagovska \\ Department of Technology of milk and milk products \\ Lviv National University of Veterinary Medicine and Biotechnologies named after S. Z. Gzhytskyi \\ 50 Pekarska str., Lviv, Ukraine, 79010 \\ gachak61@mail.ru
}

\footnotetext{
Abstract

There was grounded the expedience of using cryopowder "Pumpkin" in the technology of sweet and salt cheese masses. The possibility of using cryopowder "Pumpkin" as a component of therapeutic and prophylactic cheeses masses was studied. The main factors of introduction of cryoadditive "Pumpkin" are: normative organoleptic properties of product and its daily norm. The production of cheese masses with cryoadditive "Pumpkin" provides their combination with sugar or salt.

The use of cryoadditive "Pumpkin" needs preliminary comminution and mixing them with sugar-sand or salt. The receipts of 4 types of cheese masses with cryoadditive "Pumpkin" (two fatless and two semi-fat ones) were elaborated. At introduction of cryoadditive "Pumpkin" in cheese masses their food value increased. The organoleptic, technological and commodity characteristics of these cheese masses were studied. It was established, that the color of sweet cheese masses was cream with separate yellow dots of comminuted powder-like cryoadditive and the color of salt cheese masses was, correspondingly, yellow. In sweet cheese masses the distinct smell of cryoadditive was perceptible, whereas in salt cheese masses it was fresh, sour-milk. The flavor of studied samples was more expressed in sweet cheese masses. The offered cheese masses had pleasant, original commodity look, normative physical-chemical characteristics.

The titrated acidity of studied samples of salt cheese masses was $124-130^{\circ} \mathrm{T}$, moisture $\mathrm{ms}-62-60 \%$ and dry substances $-40-38 \%$, and titrated acidity of studied samples of sweet cheese masses was $126-134{ }^{\circ} \mathrm{T}$, moisture ms $63-66 \%$ and dry substances $-34-37 \%$.

The offered production widens the assortment of milk products of therapeutic and prophylactic direction.

Keywords: cheese masses, bioadditives, phytoadditives, pumpkin, therapeutic and prophylactic products, food technologies.

DOI: $10.21303 / 2504-5695.2017 .00306$

(C) Bogdan Gutyj, Yuriy Hachak, Jaroslava Vavrysevych, Volodimyra Nagovska
}

\section{Introduction}

Taking into account the modern ecological condition, there is an acute need in improvement of the nutrition structure of population at the expanse of raising quality, biological value and gustatory characteristics of products [1-3]. The important direction at that is their enrichment with 
vitamins, mineral and immune substances, especially with ones on natural base $[4,5]$. The skillful combination of cryoadditives (as bioadditives) with "milk" base has great prospects in both bio-technological and social aspects. The cryopowders are wholesome for both children and adults [1]. It seems more attractive to use the natural vegetable bioadditives that include significant number of deficit microelements and other biologically active substances in cheese masses technology [1,6].

It remains extremely important to use the component of vegetable origin in milk production $[7,8]$. The combination of vegetable and animal raw material allows maximally correct the content and properties of products [9]. The use of such additives allows refill the deficit of essential food substances and increase the non-specific resistance of organism to the effect of unfavorable environmental factors [10].

The elaboration and production of food goods of therapeutic and prophylactic direction including milk ones is extremely urgent. In such connection there was offered the research as to the study of the possibility of using cryopowder "Pumpkin" as phytoadditive in technology of salt and sweet cheese masses of therapeutic and prophylactic direction.

\section{Materials and Methods}

The experimental part was carried out under conditions of the laboratory of production workshops of "Prometey" LTD ("Lviv milk factory", Ukraine) and the laboratory of the department of milk and milk products technology of Lviv national university of veterinary medicine and biotechnologies, named after C. Z. Gzhytskyi (Fig. 1).
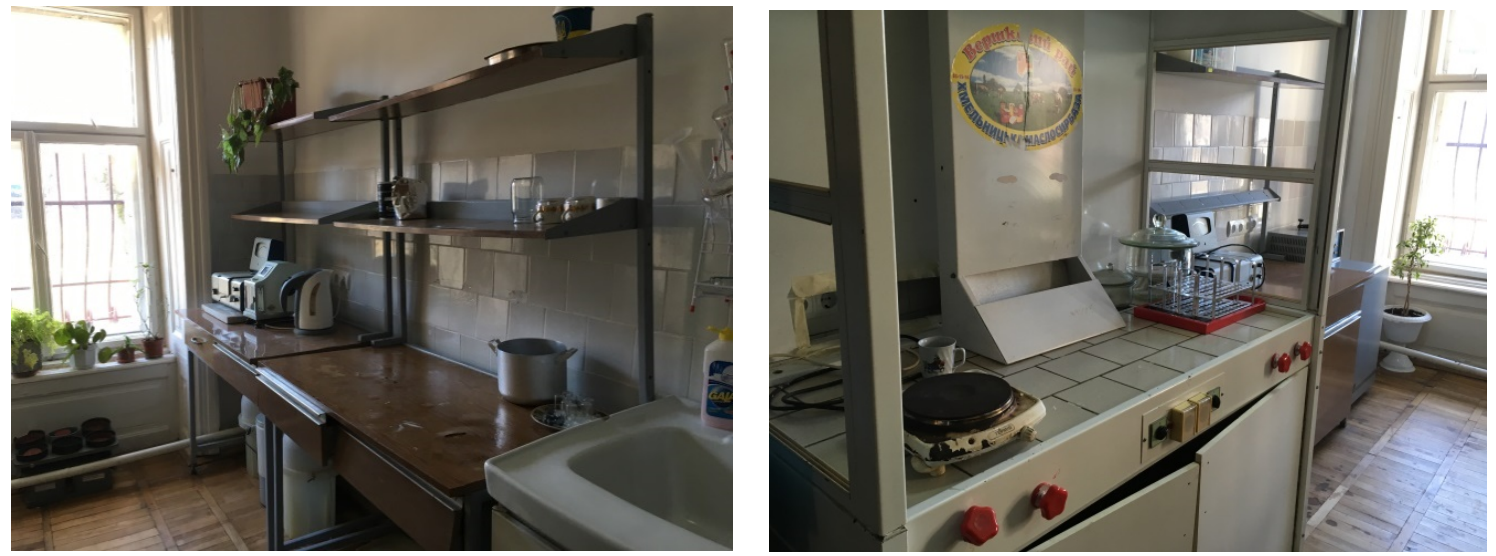

Fig. 1. Laboratory of the department of milk and milk products technology of Lviv national university of veterinary medicine and biotechnologies, named after C. Z. Gzhytskyi

The unified bioadditive "Pumpkin" (CSC PA “Gummy") (Fig. 2), taken and calculated, based on its prophylactic and therapeutic doses for 100-150 g of cheese mass was used for the study. The way of cheese masses production includes the receiving of cheese base - normative sour-milk fatless cheese or with fms $5 \%$, its cooling, placing in mixing machine and adding of biologically active pumpkin additive, preliminary prepared, according to the receipt with sugar or salt at continuous mixing, their packing and storage.

The receipt of cheese masses was recalculated for industrial, namely: with calculation for $1000 \mathrm{~kg}$ of ready product.

Cryoadditive "Pumpkin" (TC 9184-017-51784815-09) is a unified bioadditive. It is recommended for people with liver, gallbladder, cardio-vascular diseases, at gastritis, colic pains, obesity, sleep disorders. This bioadditive is useful at anemia and nervous system disorder. It is recommended for pregnant women as a remedy for toxicosis. Pumpkin strengthens the immune system and activates the processes of stomach ulcers healing.

The experiments included the revelation of optimal ratio of cryopowder and components of "milk bases". At the same time the organoleptic, technological and laboratory parameters of milk bases were studied. 


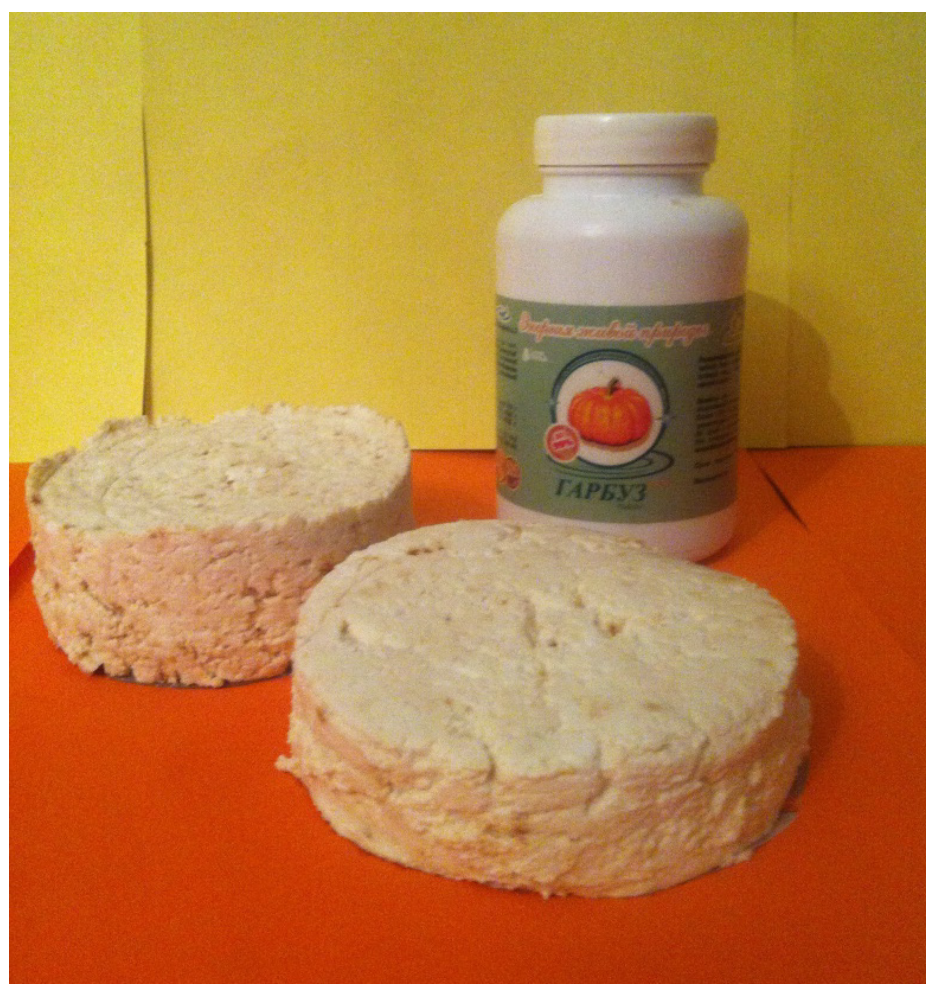

Fig. 2. Cryopowder "Pumpkin" and cheese mass

The determinative factor at using Cryoadditive "Pumpkin" was preservation of the normative characteristics of sweet and salt cheese additives (Fig. 3).

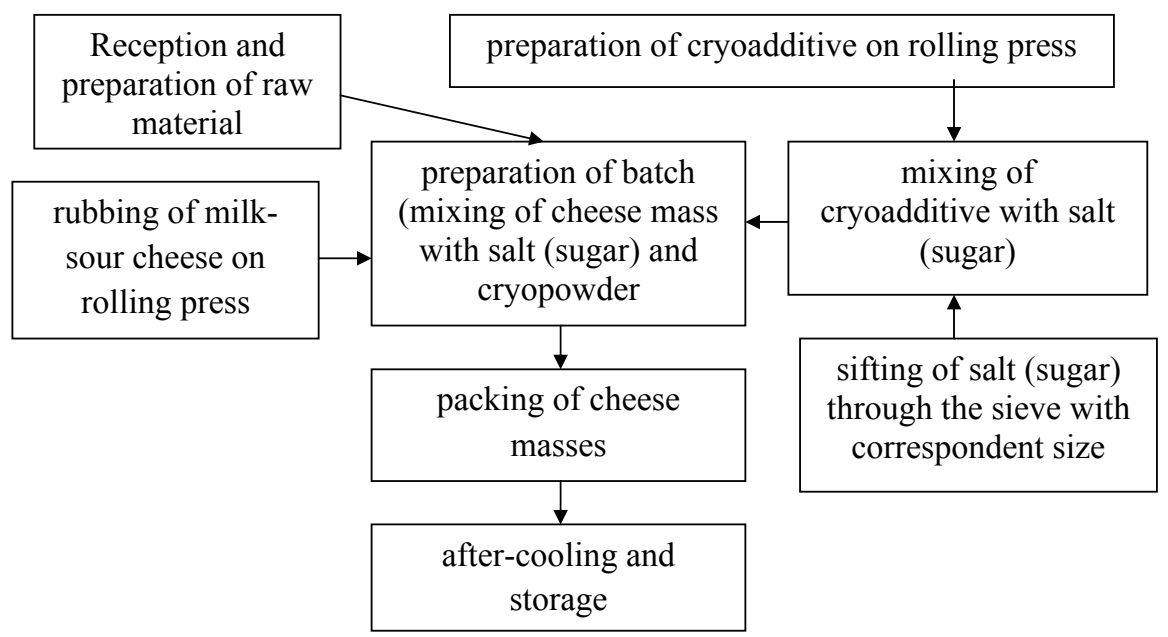

Fig. 3. Technological scheme of production of salt (sweet) cheese masses with microelements

The qualitative assessment of studied cheese products was carried out according to conventional methods, normative documents. The taking of samples of ready products was carried out according to SST 26809-86 "Milk and milk products. Rules of reception. Methods of taking and preparation of samples for analysis" and SSTC ISO 707-2002 "Milk and milk products". Regulations for taking of samples SSTC ISO 5538:2004 "Milk and milk products. Taking of samples. Control of quality parameters".

The selection of point samples of cheese masses is realized by lowering probe to the package bottom. Three point samples can be separated: one from the center, other ones at the distance 
2-3 cm from the side wall of package. The mass of combined sample is $500 \mathrm{~g}$, sample for research 100, and the one of products with stuffs is $150 \mathrm{~g}$. The mass of combined sample in consumer package is 100 or $150 \mathrm{~g}$.

The estimation of cheese masses acidity by titration method:

1. To rub the batch of sour-milk cheese $(5 \mathrm{~g})$ in porcelain pestle and grind it, to add $50 \mathrm{ml}$ of distilled water with temperature $35-40{ }^{\circ} \mathrm{C}$.

2. To add 3 drops of phenolphthalein and to titrate by $0,1 \mathrm{~N}$ solution of alkali to the faint rose coloration that doesn't disappear during $1 \mathrm{~min}$.

3. To calculate the acidity of sour-milk cheese, to multiply the alkali quantity (ml), spent for titration, by 20 . The difference between parallel calculations must not be more than $4{ }^{\circ} \mathrm{T}$.

The study of moisture in sour-milk cheese by express-method:

1. To place the porcelain cup with glass stick and 20-25 g of sand in drying cupboard for 1 hour. At temperature $102-105^{\circ} \mathrm{C}$.

2. To weigh out in cup $5 \mathrm{~g}$ of sour-milk cheese, to mix it with sand and to place for $20 \mathrm{~min}$. in cupboard at temperature $160-165^{\circ} \mathrm{C}$. To weigh it again.

3. The moisture quantity was calculated by the formula:

$$
\mathrm{M}=\frac{\mathrm{m}-\mathrm{ml}}{5} \cdot 100
$$

where $\mathrm{M}$ - moisture content in sour-milk cheese (\%); $\mathrm{m}$ - mass of cup with sand and cheese before drying $(\mathrm{g}) ; \mathrm{ml}$ - mass of cup after drying $(\mathrm{g})$.

The estimation of fat mass share in cheese products

The fat quantity in milk products is estimated using cream or milk fat butyrometers.

The technique of estimation of fat mass share (fms) in cream butyrometer:

1. To balance butyrometer on technochemical scales and to weigh $5 \mathrm{~g}$ of cheese mass in it.

2. To add $5 \mathrm{ml}$ of water, $10 \mathrm{ml}$ of sulfuric acid and $1 \mathrm{ml}$ of isoamyl alcohol.

3. To cover butyrometer with rubber cork, to place in water bath at water temperature $65 \pm 2{ }^{\circ} \mathrm{C}$, periodically shaking for solving protein.

To center it for $5 \mathrm{~min}$. with speed no less than 1000 turn $/ \mathrm{min}$.

4. To place butyrometer in water bath for $5 \mathrm{~min}$. at temperature $65 \pm 2{ }^{\circ} \mathrm{C}$ cork down.

5. To calculate the fat content by scale. The butyrometer indicates the fat content in sourmilk cheese in percents. The difference between parallel calculations of microbiological control at sour-milk cheese production must not be more than $0,5 \%$.

Microbiological studies of product are carried out no later than in 4 hours from the moment of taking samples. The preparation of samples and solutions of cheese masses for microbiological studies were carried out according to SSTC “IDF 122C:2003". The samples of cheese mass were taken according to SSTC 73-57: 2013 "Milk and milk products. The methods of microbiological studies".

Microbiological preparations were studied according to BS 49113-77. BCBG were estimated by inoculation of product solution on Kessler medium.

\section{Results}

The optimal receipt of salt and sweet cheese masses of different fattiness using cryopowder "Pumpkin" is presented in the Table 1. It was established, that with increase of fat mass share of milk raw material the quantity of cryoadditive "Pumpkin" in the receipt increases too. Thus, for $1000 \mathrm{~kg}$ of ready product for salt cheese masses the quantity of cryopowder increase from 9,75 to $13,59 \mathrm{~kg}$, whereas for sweet cheese masses the quantity of cryopowder was a bit higher and varied correspondingly from 17,23 to $33,61 \mathrm{~kg}$.

Such change of amount of cryopowder "Pumpkin" in cheese masses is connected with introduction of more sugar in fatter cheese mass and with fat of milk base itself that essentially intensifies the gustatory perception of the offered bioadditive. 
The analysis of organoleptic characteristics of cheese masses with cryopowder "Pumpkin" shows that they don't essentially change and mainly completely correspond to the normative requirements. Thus, the color of sweet cheese masses was light-cream and cream, whereas the color of salt samples with cryoadditive was light-yellow and yellow.

Table 1

The recommended receipts of cheese masses with addition of cryoadditive "Pumpkin"

\section{Cheese masses content}

Fatless with cryopowder

Sweet cheese masses

\section{Cheese masses}

Semi-fat $(4,8 \%)$ with cryopowder

\begin{tabular}{ccc}
\hline Fatless cheese & 862,07 & - \\
$\mathrm{s} / \mathrm{m}$ cheese with fms $5 \%$ & - & 840,34 \\
Sugar-sand & 120,69 & 126,05 \\
Cryopowder & 17,23 & 33,61 \\
Totally & 1000 & 1000 \\
\hline Satless cheese & Salt cheese masses & - \\
s/m cheese with fms $5 \%$ & 974,66 & 970,87 \\
Table salt & - & 15,54 \\
Cryopowder & 15,59 & 13,59 \\
Totally & 9,75 & 1000
\end{tabular}

The smell of cheese masses remained fresh, sour-milk. But in sweet samples the distinctly expressed smack and smell of pumpkin was perceived. The flavor of studied samples was sweet or salt. The pumpkin smack was more expressed in sweet samples. The consistence of studied samples was homogenous, pasty, the separate dots of cryopowder were present.

The other important group of parameters for description of cheese masses is their physical-chemical characteristics. The physical-chemical parameters of studied samples of sweet and salt cheese masses with cryopowder are presented in the Table 2.

The titrated acidity of studied samples of salt cheese masses was $124-130^{\circ} \mathrm{T}$, ms of moisture $62-60 \%$ and dry substances $-40-38 \%$, and titrated acidity of studied samples of sweet cheese masses had $126-134^{\circ} \mathrm{T}$, ms of moisture $63-66 \%$ and dry substances $-34-37 \%$.

The analysis of figure material of the Table 3 testifies that the addition of cryopowder has certain influence also on physical-chemical characteristics.

The increase or decrease of microorganism quantity can take place in the process of production and storage of cheese masses. The microorganisms come with output raw material from the surface of technological equipment and communications. At breaking of sanitary-hygienic conditions of production the development of pathogenic microflora is possible that results in creation of toxic substances that causes food intoxications. That is why the study of microflora at storage of cheese masses is important at their production. The dynamics of microbiological parameters of cheese masses at storage is presented in the Tables 3, 4 . 
Table 2

The main physical-chemical parameters of cheese masses with cryopowder "Pumpkin"

\begin{tabular}{|c|c|c|c|c|c|}
\hline \multirow[b]{2}{*}{ Cheese mass name } & \multirow[b]{2}{*}{ Acidity $\left({ }^{\circ} \mathbf{T}\right)$} & \multicolumn{3}{|c|}{ Mass chare } & \multirow[b]{2}{*}{ Food value (kcal/100g) } \\
\hline & & Moisture & $\begin{array}{c}\text { Dry } \\
\text { substances }\end{array}$ & Fat, \% & \\
\hline Normative values of cheese masses & $120-140$ & $60-70$ & - & s/f; 4-6 & $120-180$ \\
\hline $\begin{array}{l}\text { Salt cheese masses: fatless and } \\
\text { semi/fat with cryopowder "Pumpkin" }\end{array}$ & $130 / 124$ & $60 / 62$ & $40 / 38$ & $\mathrm{~s} / \mathrm{f} ; 4,8$ & $118 / 164$ \\
\hline $\begin{array}{l}\text { Sweet cheese masses: fatless and } \\
\text { semi/fat with cryopowder "Pumpkin" }\end{array}$ & $134 / 126$ & $63 / 66$ & $37 / 34$ & s/f; 4,6 & $128 / 174$ \\
\hline
\end{tabular}

Table 3

The results of microbiological studies of sweet cheese masses with cryopowder at their storage

\begin{tabular}{|c|c|c|c|}
\hline \multirow{2}{*}{ Day } & \multirow{2}{*}{$\begin{array}{c}\text { The studied microbiological parame- } \\
\text { ters at storage of product }\end{array}$} & \multicolumn{2}{|c|}{ Sweet cheese mass } \\
\hline & & Fatless with cryopowder & Semi/fat with cryopowder \\
\hline
\end{tabular}

Acidity, ${ }^{\circ} \mathrm{T}$

1

$\mathrm{BCBG}$

Microbic landscape

Acidity, ${ }^{\circ} \mathrm{T}$

2

BCBG

Microbic landscape

Acidity, ${ }^{\circ} \mathrm{T}$

3

BCBG

Microbic landscape

Acidity, ${ }^{\circ} \mathrm{T}$

BCBG

4

Microbic landscape

130

Solution $10^{-5}$ were not detected

Sour-milk streptococci

134

Solution $10^{-4}$ were not detected

Sour-milk streptococci

138

Solution $10^{-3}$ were not detected

Sour-milk streptococci

144

138

Solution $10^{-3}$ were not detected

Sour-milk streptococci

3-4 micrococci; 1-2 bands
Sour-milk streptococci 1-2 micfrococci

Thus, on the base of the studies there was grounded the expedience of using cryopowder "Pumpkin" in technology of cheese masses of different fat and type that increases their biological value. 
Table 4

The results of microbiological studies of salt cheese masses with cryopowder at their storage

\begin{tabular}{|c|c|c|c|}
\hline \multirow{2}{*}{ Day } & \multirow{2}{*}{$\begin{array}{l}\text { The studied microbiological parame- } \\
\text { ters at storage of product }\end{array}$} & \multicolumn{2}{|c|}{ Salt cheese mass } \\
\hline & & Fatless with cryopowder & Semi/fat with cryopowder \\
\hline \multirow{4}{*}{1} & Acidity, ${ }^{\circ} \mathrm{T}$ & 134 & 126 \\
\hline & $\mathrm{BCBG}$ & \multicolumn{2}{|c|}{ Solution $10^{-5}$ were not detected } \\
\hline & Microbic landscape & \multicolumn{2}{|c|}{ Sour-milk streptococci } \\
\hline & Acidity, ${ }^{\circ} \mathrm{T}$ & 136 & 130 \\
\hline \multirow[t]{3}{*}{2} & $\mathrm{BCBG}$ & \multicolumn{2}{|c|}{ Solution $10^{-4}$ were not detected } \\
\hline & Microbic landscape & \multicolumn{2}{|c|}{ Sour-milk streptococci } \\
\hline & Acidity, ${ }^{\circ} \mathrm{T}$ & 138 & 136 \\
\hline \multirow[t]{3}{*}{3} & $\mathrm{BCBG}$ & \multicolumn{2}{|c|}{ Solution $10^{-3}$ were not detected } \\
\hline & Microbic landscape & \multicolumn{2}{|c|}{$\begin{array}{l}\text { Sour-milk streptococci } \\
1-2 \text { micrococci }\end{array}$} \\
\hline & Acidity, ${ }^{\circ} \mathrm{T}$ & 142 & 140 \\
\hline \multirow{2}{*}{4} & $\mathrm{BCBG}$ & \multicolumn{2}{|c|}{ Solution $10^{-3}$ were not detected } \\
\hline & Microbic landscape & $\begin{array}{l}\text { Sour-milk streptococci } \\
3-4 \text { micrococci }\end{array}$ & Sour-milk streptococci \\
\hline
\end{tabular}

\section{Conclusions}

There was grounded the expedience of using cryopowder "Pumpkin" in technology of sweet and salt cheese masses. The optimal dose of cryoadditive "Pumpkin" as a component of therapeutic-prophylactic cheese masses was offered.

Some receipt differences between sweet and salt cheese masses were established. At the study of organoleptic, physical-chemical and biological characteristics it was established, that the color of salt cheese masses with cryoadditive was yellow, whereas the color of sweet ones was cream with separate yellow dots of comminuted powder-like cryoadditive. The smell of salt cheese masses remained fresh, sour-milk, whereas in sweet ones the distinctly expressed smell of cryoadditive was perceptible. The flavor of studied samples was more expressed in sweet cheese masses. The consistence of cheese masses with addition of cryoadditive "Pumpkin" was homogenous, pasty and tender.

At the study of organoleptic parameters of cheese masses using cryoadditive "Pumpkin" it was established, that the color of sweet cheese masses was cream with separate yellow dots of comminuted powder-like cryoadditive, whereas the color of salt cheese masses was correspondingly yellow. In sweet cheese masses the distinctly expressed smell of cryoadditive was perceived, whereas in salt ones it remained fresh, sour-milk.

The offered cheese masses had pleasant original commodity look, normative physical-chemical characteristics.

So, the use of vegetable components as bioadditives in technological process of cheese masses is important from both theoretical and practical points of view. The experiments in this direction are prospective and interesting; they contain practical recommendations for production. The result is the new product, useful for potential consumers.

\section{References}

[1] Hachak, U. R., Vavrysevych, J. (2016). The use of cryopowder «pumpkin» in the technology of cheese masses with different fat content. Scientific Messenger of LNU of Veterinary Medicine and Biotechnology, 18 (2 (68)), 41-46. doi: 10.15421/nvlvet6808 
[2] Mamone, G., Picariello, G., Caira, S., Addeo, F., Ferranti, P. (2009). Analysis of food proteins and peptides by mass spectrometry-based techniques. Journal of Chromatography A, 1216 (43), 7130-7142. doi: 10.1016/j.chroma.2009.07.052

[3] Piska, I., Stetina, J. (2004). Influence of cheese ripening and rate of cooling of the processed cheese mixture on rheological properties of processed cheese. Journal of Food Engineering, 61 (4), 551-555. doi: 10.1016/s0260-8774(03)00217-6

[4] Barbano, D. M., Margolies, B. (2016). Critical factors for evaluation of cheese yield performance and fat loss in large cheese factories. Journal of Animal Science, 94 (supplement 5), 269-270. doi: 10.2527/ jam2016-0566

[5] Bejarano Toro, E. E., Sepulveda Valencia, J. U., Restrepo Molina, D. A. (2016). Characterization of a processed cheese spread produced from fresh cheese (quesito antioqueño). Revista Facultad Nacional de Agronomía, 69 (2). doi: 10.15446/rfna.v69n2.59146

[6] Fiol, C., Prado, D., Mora, M., Alava, J. I. (2016). Nettle cheese: Using nettle leaves (Urtica dioica) to coagulate milk in the fresh cheese making process. International Journal of Gastronomy and Food Science, 4, 19-24. doi: 10.1016/j.ijgfs.2016.05.001

[7] Shabani, J., Sarfarazi, M., Mirzaei, H., Jafari, S. M. (2016). Influence of the sunflower oil content, cooking temperature and cooking time on the physical and sensory properties of spreadable cheese analogues based on UF white-brined cheese. International Journal of Dairy Technology, 69 (4), 576-584. doi: 10.1111/1471-0307.12305

[8] Smith, G. P. S., Holroyd, S. E., Reid, D. C. W., Gordon, K. C. (2016). Raman imaging processed cheese and its components. Journal of Raman Spectroscopy, 48 (3), 374-383. doi: 10.1002/jrs.5054

[9] Katz, G., Merin, U., Bezman, D., Lavie, S., Lemberskiy-Kuzin, L., Leitner, G. (2016). Real-time evaluation of individual cow milk for higher cheese-milk quality with increased cheese yield. Journal of Dairy Science, 99 (6), 4178-4187. doi: 10.3168/jds.2015-10599

[10] Ferrao, L. L., Silva, E. B., Silva, H. L. A., Silva, R., Mollakhalili, N., Granato, D., Freitas, M. Q., Silva, M. C., Raices, R. S. L., Padilha, M. C., Zacarchenco, P. B., Barbosa, M. I. M. J., Mortazavian, A. M., Cruz, A. G. (2016). Strategies to develop healthier processed cheeses: Reduction of sodium and fat contents and use of prebiotics. Food Research International, 86, 93-102. doi: 10.1016/j.foodres.2016.04.034 